- ACORN Australan college of | JOURNAL OF PERIOPERATIVE NURSING

Volume 34 | Issue 3

Article 8

8-30-2021

\title{
Journal of Perioperative Nursing: Fulfilling its mission and achieving its vision
}

Follow this and additional works at: https://www.journal.acorn.org.au/jpn

Part of the Perioperative, Operating Room and Surgical Nursing Commons

(c) (i)

This work is licensed under a Creative Commons Attribution 4.0 License.

\section{Recommended Citation}

Duff, Jed (2021) "Journal of Perioperative Nursing: Fulfilling its mission and achieving its vision," Journal of Perioperative Nursing: Vol. 34 : Iss. 3 , Article 8.

Available at: https://doi.org/10.26550/2209-1092.1148

https://www.journal.acorn.org.au/jpn/vol34/iss3/8

This Editorial is brought to you for free and open access by Journal of Perioperative Nursing. It has been accepted for inclusion in Journal of Perioperative Nursing by an authorized editor of Journal of Perioperative Nursing. 
Professor Jed Duff

PhD, RN, FACORN

Editor, Journal of Perioperative Nursing

Professor, School of Nursing Faculty

of Health, Queensland University of

Technology Nursing and Midwifery

Research Centre, Royal Brisbane and

Women's Hospital

journaleditor@acorn.org.au

\section{Journal of Perioperative Nursing: Fulfilling its mission and achieving its vision}

The Journal of Perioperative Nursing (JPN) continues to fulfil its mission to be the trusted source of evidence for perioperative nurses and is within reach of achieving its vision to be the world's leading perioperative nursing journal. In this editorial, I take the opportunity to celebrate the journal's achievements over the past two years.

The last two years have seen JPN climb the international journal rankings. JPN is ranked $11^{\text {th }}$ among all medical-surgical nursing journals in the most recent list, placing us above the AORN Journal (ranked $13^{\text {th }}$ ), the Journal of Perioperative Practice (ranked $18^{\text {th }}$ ) and just below the Journal of Perianaesthesia Nursing (ranked $8^{\text {th }}$ ). JPN is well on track to achieving its vision of being the world's leading perioperative nursing journal.

JPN's governance and publishing practices were reviewed and modified to meet the internationally recognised Principles of Transparency and Best Practice in Scholarly Publishing ${ }^{1}$. Unfortunately, many online journals exist purely for profit and do not abide by scholarly principles. We have worked hard to set ourselves apart from these unscrupulous operators by developing robust and transparent policies and processes.

An Editorial Advisory Board (EAB) was established in 2020 as part of the governance review. The EAB comprises highly regarded perioperative nurses from Australia and abroad with expertise in clinical practice, management, governance and academia (see Table 1).
Three Associate Editors were also appointed: Dr Paula Foran, Dr Lois Hamlin and Dr Oya Gumuskaya. The EAB and editorial team have set the journal's strategic direction and monitored our progress towards our goals.

The editorial team has worked hard to actively disseminate our articles to the perioperative community in an easily accessible format. You have probably received the monthly email update from me, including a summary and link to the latest published articles. Our Associate Editor, Dr Oya Gumuskaya, is also working with our authors to produce social media content that can be shared widely to help highlight publications.

The emerging scholars section remains one of the most popular sections of our journal. Our Associate Editor, Dr Paula Foran, works with students and first-time authors to support them through writing and publishing a manuscript. This initiative is part of the journal's commitment to building the capacity of perioperative nurses in research and scholarship.

This year we continued the tradition of awarding a paper of the year. The paper of the year for 2020 was awarded to Noriko Ogo and $\mathrm{Dr}$ Paula Foran for their paper, 'The effectiveness and compliance of surgical face mask wearing in the operating suite environment: An integrated review'. The article had the highest downloads (over 1600 to date) of all papers published in JPN during 2020. 
Table 1: Editorial Advisory Board members

\begin{tabular}{|c|c|}
\hline Name & Role \\
\hline Juliet Asbery & Chair, Perioperative Nurses College New Zealand \\
\hline Prof. Karen Clark-Burg & Dean, University of Notre Dame School of Nursing \\
\hline Rebecca East & Chief Executive Officer, ACORN \\
\hline Dr Paula Foran & University of Tasmania \\
\hline Prof. Brigid Gillespie & Professor of Patient Safety, Griffith University \\
\hline Jenny Green & Nursing Lecturer, Massey University \\
\hline Dr Oya Gumuskaya & Lecturer, University of Newcastle \\
\hline Dr Toni Hains & Nurse Practitioner / PNSA \\
\hline Dr Lois Hamlin & ACORN Journal Editor Emerita \\
\hline Claire Kennedy & $\begin{array}{l}\text { Australian Day Surgery Nurses Association (ADSNA), } \\
\text { past president }\end{array}$ \\
\hline Dr Judy Mundy & Lecturer, Queensland University of Technology \\
\hline Fiona Newman & $\begin{array}{l}\text { Australian College of PeriAnaesthesia Nurses } \\
\text { (ACPAN), President }\end{array}$ \\
\hline A/Prof. Pat Nicholson & Perioperative Coordinator, Deakin University \\
\hline A/Prof. Sonya Osborne & $\begin{array}{l}\text { Associate Head (Research), University of Southern } \\
\text { Queensland }\end{array}$ \\
\hline Jo Perry & Perioperative Coordinator \\
\hline A/Prof. Nicholas Ralph & University of Southern Queensland \\
\hline Judy Smith & Perioperative Coordinator, University of Technology \\
\hline $\begin{array}{l}\text { Sharron Smyth- } \\
\text { Demmon }\end{array}$ & $\begin{array}{l}\text { Perioperative Coordinator, Australian College of } \\
\text { Nursing }\end{array}$ \\
\hline $\begin{array}{l}\text { A/Prof. Victoria } \\
\text { Steelman }\end{array}$ & University of Iowa, Associate Professor Emerita \\
\hline
\end{tabular}

The EAB is committed to open access publishing, which means that any perioperative nurse in the world can access our journal anywhere and at any time. We believe that perioperative nursing knowledge should not be locked behind paywalls but should be readily and freely available to support evidence-based care.
Open access is also beneficial to our authors. Open access can make the difference between being cited and not cited. The easier it is to access a paper, the more likely it is to be downloaded, read and cited. JPN has been listed in the Directory of Open Access Journals (DOAJ) in recognition of this commitment. Listing in the directory signifies we are a quality, open access journal that follows best practice scholarly publishing principles.

In the past two years, JPN has had 75000 downloads - evidence that we are achieving our mission. And the annual number of downloads per year grows exponentially, with almost 50000 in the past twelve months. The top ten countries for downloads in this period were Australia, United States of America, United Kingdom, Canada, New Zealand, India, Philippines, Ireland, China and Singapore.

Multidisciplinary and international submissions that address the journal's aim and are relevant to the global perioperative nursing community are welcomed. As the journal's ranking and reputation has grown, we have seen more international perioperative nurses and other perioperative health care professionals submit papers.

I want to thank the EAB, our Managing Editor, Eleanor Tan, the ACORN staff and the dedicated peer reviewers for all their hard work. These past two years have been an exciting and successful period for the journal. I am confident that we can achieve even greater heights in the coming two years.

\section{Reference}

1. Committee on Publication Ethics (COPE). Principles of Transparency and Best Practice in Scholarly Publishing [Internet]. Eastleigh, Hampshire: COPE; 2014 [updated 2018 January 15; cited 2021 August 23]. Available from: https://doi.org/10.24318/cope.2019.1.12. 